\title{
Clinical Results with a B Cell Activating Anti-CD73 Antibody for the Immunotherapy of COVID-19
}

\section{Authors}

Richard A. Miller ${ }^{1}$, Pramod Guru ${ }^{2}$, Philippe Bauer ${ }^{3}$, Jorge Robles ${ }^{4}$, Christian Tomaszewski ${ }^{4,5}$, J. Scott Overcash $^{6}$, Michael Waters ${ }^{7}$, Miriam Cameron ${ }^{8}$, Julián Olalla Sierra ${ }^{9}$, Haider Mashhedi ${ }^{1}$, Mehrdad Mobasher ${ }^{1}$, James Janc ${ }^{1}$, Jenny A. Rudnick ${ }^{1}$, Shenshen Hu${ }^{1}$, William B. Jones ${ }^{1}$, Long Kwei $^{1}$, Suresh Mahabhashyam ${ }^{1}$, Stephen B. Willingham ${ }^{1}$, Gerard Criner $^{10}$.

\author{
Affiliations \\ ${ }^{1}$ Corvus Pharmaceuticals, Burlingame, CA, USA. \\ ${ }^{2}$ Mayo Clinic, Jacksonville, FL, USA. \\ ${ }^{3}$ Mayo Clinic, Rochester, MN, USA. \\ ${ }^{4}$ El Centro Regional Medical Center, El Centro, CA, USA. \\ ${ }^{5}$ University of California, San Diego, CA, USA. \\ ${ }^{6}$ Sharp Grossmont Hospital, La Mesa, CA, USA. \\ ${ }^{7}$ Sharp Chula Vista Medical Center, Chula Vista, CA, USA. \\ ${ }^{8}$ Holy Cross Hospital, Silver Spring, MD, USA. \\ ${ }^{9}$ Hospital Costa del Sol, Marbella, Spain. \\ ${ }^{10}$ Temple University Hospital, Philadelphia, PA, USA.
}

Corresponding author: Richard Miller, Corvus Pharmaceuticals, Phone: 650-900-4521; rmiller@,corvuspharma.com.

\section{Keywords}

CD73, COVID-19, SARS-CoV-2, RBD, vaccine, antibody, B cells, T cells

\section{Conflict of interest statement}

A subset of authors (RAM, HM, MM, JJ, JAR, SH, WBJ, LK, SM, SBW) are employees, consultants or shareholders of Corvus Pharmaceuticals. RAM and SBW are inventors on patents owned by Corvus Pharmaceuticals related to this work. All other authors have nothing additional to disclose.

\section{ABSTRACT}

Robust polyclonal humoral immune responses have the potential to generate a diverse set of antibodies to neutralize and eliminate viruses such as SARS-CoV-2 and protect against 
transmission, re-infection and the evolution of variants that evade immunity. CD73 is present on subsets of human B and $\mathrm{T}$ cells where it plays a role in lymphocyte activation and migration. CD73 also functions as an ectoenzyme that converts AMP into immunosuppressive adenosine. We have developed a humanized anti-CD73 antibody, mupadolimab (CPI-006), that blocks CD73 enzymatic activity and activates $\mathrm{CD} 73^{\mathrm{POS}} \mathrm{B}$ cells, thereby inducing differentiation into plasmablasts, immunoglobulin class switching, and antibody secretion independent of the adenosine modulatory activity. These effects suggest mupadolimab may enhance the magnitude, diversity, and duration of anti-viral responses in patients with COVID-19. This hypothesis was tested in a dose escalation phase 1 trial in 29 hospitalized patients with COVID-19. Single doses of $0.3 \mathrm{mg} / \mathrm{kg}-5 \mathrm{mg} / \mathrm{kg}$ mupadolimab were well tolerated with no drug related adverse events. Doses greater than $0.3 \mathrm{mg} / \mathrm{kg}$ resulted in rapid generation of IgG and IgM to SARS-CoV-2 significantly above titers measured in convalescent controls, with elevated IgG titers sustained for more than 6 months beyond presentation of symptoms. Based on these findings, a randomized double-blind, placebo-controlled Phase 3 study in hospitalized patients was initiated. The primary endpoint was proportion of patients alive and free from respiratory failure within 28 days. This trial was discontinued early during the period of waning COVID-19 incidence after enrolling 40 patients. Although underpowered, results from this trial suggest improvement in the primary and key secondary endpoints in patients treated with single doses of $2 \mathrm{mg} / \mathrm{kg}$ and 1 $\mathrm{mg} / \mathrm{kg}$ compared to placebo. The presumed mechanism of action, stimulation of B cells, may represent a novel approach to immunotherapy of COVID-19 and other viral infections.

\section{INTRODUCTION}

COVID-19 is a viral disease caused by the severe acute respiratory syndrome coronavirus 2 (SARS-CoV-2). Despite the introduction of vaccines and passive monoclonal anti-viral antibodies, there remains an urgent need for therapies that can improve survival, clinical outcomes, and reduce the requirements for intensive supportive care and prolonged hospitalization.[1-3] Recent emergence of viral variants and deterioration of immunity with time following vaccination have highlighted these needs. In addition, immunocompromised individuals have shown vulnerability to infection despite vaccination.[4] There is also evidence that chronic or persistent infection with SARS-CoV-2 may lead to variants with the potential to escape immunity. Anti-inflammatory drugs such as dexamethasone, tocilizumab, baricitinib and tofacitinib have shown only slight clinical benefit in selected subgroups of hospitalized patients.[5-8] The inadequate results to date and continued surge in viral spread and disease, demonstrate the urgent need for new approaches to prevent, control or eradicate viral infection, especially those infections resulting in persistent or serious disease. 
CD73 is expressed on subsets of human $\mathrm{CD} 4^{\mathrm{POS}}$ and $\mathrm{CD} 8^{\mathrm{POS}} \mathrm{T}$ cells, germinal center follicular dendritic cells, and both naïve and class switched memory B cells where it is thought to play a role in lymphocyte trafficking and cellular activation.[9-14] CD73 also functions as an ectonucleotidase that hydrolyzes extracellular adenosine monophosphate (AMP) into immunosuppressive adenosine.[15]

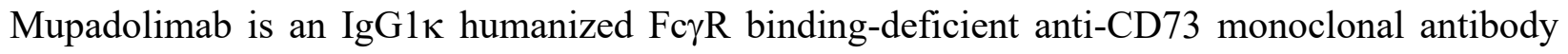
$(\mathrm{mAb})$ that activates $\mathrm{CD} 73^{\mathrm{POS}} \mathrm{B}$ cells.[16, 17] In vitro, mupadolimab induces the increased expression of markers associated with $\mathrm{B}$ cell maturation and antigen presentation, morphologic transformation to plasmablasts, and increased secretion of IgM and IgG. The unique immunologic properties of mupadolimab provided the rationale to examine its use as an immunotherapy for COVID-19 with the aim of boosting anti-viral immune responses and improving clinical outcome. We conducted an open label phase 1 trial with mupadolimab in hospitalized patients with COVID-19. Findings in this study led to the initiation of a randomized double-blind, placebo-controlled phase 3 study that was terminated early after enrollment of 40 patients due to the waning incidence of COVID-19 in the U.S. in mid 2021. The clinical results of these trials are reported here. The findings suggest that immune-stimulation with mupadolimab offers a novel approach to treating COVID-19, and potentially other infectious diseases, which relies on the stimulation of B cells in the presence of antigens from an infectious agent to enhance immunity.

\section{RESULTS}

\section{Mupadolimab Elicits Antigen Specific Immunity in an Animal Model}

We utilized an animal model to determine if mupadolimab could enhance antigen-specific immune responses to SARS-CoV-2. Mupadolimab does not bind to mouse CD73, so NSGSGM3 mice were used. Though these mice have no mouse B, T, or NK cells, they have been reconstituted with a human immune system and do have human B cells that can be activated with mupadolimab.[18, 19] NSG-SGM3 mice were immunized with purified SARS-CoV-2 trimeric spike protein (TS) in incomplete adjuvant, along with mupadolimab or a human IgG1 isotype control. Mice vaccinated with the TS plus mupadolimab made antigen specific human anti-TS antibodies, while mice receiving TS plus isotype control did not mount a response (Figure 1A). These antibody responses were antigen specific, as mice treated with mupadolimab made antibodies to the immunizing TS protein; but not to the control nucleocapsid SARS-CoV-2 viral protein (Figure 1B). These results demonstrate that mupadolimab stimulates antigen specific 
humoral immunity and would be expected to potentiate antibody responses to SARS-CoV-2 in patients with COVID-19.

\section{Immunotherapy of COVID-19}

\section{Phase 1 open label trial}

We conducted a Phase 1 open label, single dose-escalation trial evaluating the safety, immunologic effects and clinical outcomes in COVID-19 patients hospitalized with mildmoderate disease (NCT04464395). SARS-CoV-2 infection was confirmed by RT-qPCR (reverse transcriptase quantitative polymerase chain reaction) testing of nasal swabs and eligible patients had blood oxygen saturation of at least $92 \%$ on $\leq 5 \mathrm{~L} / \mathrm{min}$ supplemental oxygen. Cohorts of patients received doses of $0.3 \mathrm{mg} / \mathrm{kg}, 1.0 \mathrm{mg} / \mathrm{kg}, 2.0 \mathrm{mg} / \mathrm{kg}, 3.0 \mathrm{mg} / \mathrm{kg}$ or $5.0 \mathrm{mg} / \mathrm{kg}$ administered by intravenous infusion given over 5-10 minutes. Patients in the $2 \mathrm{mg} / \mathrm{kg}$ cohort were included after enrollment of the other cohorts in order to obtain additional clinical data related to dosing. Patients could receive standard care for COVID-19, including remdesivir and steroids. No patient received passive monoclonal antibody therapy and two patients received convalescent plasma. Safety and other disease assessments along with PBMC (peripheral blood mononuclear cell) and serum collection were conducted daily while patients were hospitalized and then at 7, 14, and 28 days, and at 2, 3, and 6 months after receiving mupadolimab. Clinical assessments and endpoints included time to hospital discharge and proportion of patients progressing to respiratory failure.

Table 1 shows the patient characteristics of 29 patients treated on the study. These patients all had unfavorable comorbidities or were from high risk populations. The median time post onset of symptoms (POS) to mupadolimab administration was 8 days (range 1-21). No drug related adverse events of any grade or changes in quantitative serum immunoglobulins were observed. All patients recovered with improvement of inflammatory markers and symptoms and were discharged at a median of 3.0 days after hospitalization (Table 1). No patients progressed to requiring invasive or non-invasive mechanical ventilation.

\section{Immune Responses in Mupadolimab Treated COVID-19 Patients}

IgG antibody titers against the SARS-CoV-2 TS and/or RBD (receptor binding domain) were substantially increased in all evaluable patients 28 days after a single infusion of low doses of mupadolimab (Figure 2A-B). Lower antibody titers were seen in the cohort receiving $0.3 \mathrm{mg} / \mathrm{kg}$, consistent with plasma concentrations of mupadolimab below that needed for maximum B cell activation. Serum concentrations of mupadolimab achieved levels exceeding $1 \mu \mathrm{g} / \mathrm{ml}$ for greater than 24 hours for doses of $1 \mathrm{mg} / \mathrm{kg}$ and higher; concentrations known to activate $\mathrm{B}$ cells in 
vitro.[17] IgG titers were sustained without decrement up to 6 months after POS (Figure 2C). Antibody levels reached higher titers compared to convalescent sera from recovered patients (convalescent sera collected at 4-6 weeks POS, no comorbidities, and median age of 40) (Figure 2A-B, 2D-E). Similar results in the magnitude and duration of anti-SARS-Cov-2 IgM titers (Figure 2D-E) were also observed with decreasing titers seen beyond 84 days. No correlation between time after POS and pre-treatment serum antibody levels was observed as all patients had low pre-treatment titers despite relatively long durations of COVID-19 related symptoms. Mupadolimab did not induce non-specific polyclonal antibody responses. No increase in serum antibodies to common viral antigens was observed, nor were autoantibodies to type 1 IFNs, previously associated with severe COVID-19, increased following mupadolimab treatment (data not shown).[20] Immunophenotyping of PBMCs at baseline and 14, 28, and 56-days after treatment provided preliminary evidence that mupadolimab increased the frequency of memory B cells (Figure 2F). No increase in B cells with a memory phenotype were observed in the lowest dose group $(0.3 \mathrm{mg} / \mathrm{kg})$.

We next evaluated if the anti-SARS-CoV-2 antibody responses following mupadolimab treatment correlated with increased neutralization activity in SARS-CoV-2 pseudotyped lentiviral infectivity assays. Prolonged and elevated neutralizing titers were observed in patients following mupadolimab treatment, with $\mathrm{ID}_{50}$ values up to 24,000 that persisted more than 56 days following POS (Figure 3A). Neutralizing antibody titers in patients treated with mupadolimab exceed titers reported for other hospitalized COVID-19 patients.[21, 22] We tested serum from 12 patients in the study enrolled prior to reported emergence of variants (Figure $3 \mathrm{~B}$ ). Day 28 serum from these mupadolimab treated patients effectively neutralized the B.1.1.7 variant. Nine of the 12 patients had neutralizing titers above 1:50 and 7 of the 12 patients had neutralizing titers of $>1: 100$ against the B.1.351 variant harboring both the E484K and N501Y mutations in the RBD that are reported to increase transmission and confer resistance to several neutralizing monoclonal antibodies in clinical development (Figure 3B).[23-25] These results suggest mupadolimab treatment can elicit a robust and durable polyclonal neutralizing antibody response in COVID-19 patients that is capable of providing cross-protection against emerging SARS-CoV-2 variants.

\section{Randomized Double-Blind Placebo-Controlled Trial}

\section{Clinical design and endpoints}

A Phase 3, randomized, 3-arm, placebo-controlled, double-blind, multicenter, stratified study of mupadolimab plus standard of care (SOC) versus placebo plus SOC in mild to moderately symptomatic hospitalized patients with COVID-19 was initiated. A planned 1000 participants 
would be randomized at a 1:1:1 ratio to the 3 treatment arms and stratified by the following factors: age, region of the world and comorbidities. The three treatment arms received intravenous mupadolimab $2 \mathrm{mg} / \mathrm{kg}, 1 \mathrm{mg} / \mathrm{kg}$ or placebo delivered by 5 -10-minute infusion. COVID-19 disease was confirmed by RT-qPCR or antigen testing and symptoms compatible for SARS-CoV-2. Patients with signs of acute respiratory distress syndrome (ARDS) or respiratory failure necessitating mechanical ventilation at the time of screening (and randomization) or anticipated impending need for mechanical ventilation were excluded. The primary endpoint was to compare the proportion of participants alive and respiratory failure free during the 28 days after dosing with mupadolimab plus SOC versus placebo plus SOC. An 8-point ordinal disease assessment score was used to characterize patient illness as follows:

1. Not hospitalized, no limitations on activities

2. Not hospitalized, limitation on activities and/or requiring home oxygen

3. Hospitalized, not requiring supplemental oxygen - no longer requiring ongoing medical care

4. Hospitalized, not requiring supplemental oxygen - requiring ongoing medical care (COVID-19 related or otherwise)

5. Hospitalized, requiring supplemental oxygen

6. Hospitalized, on non-invasive ventilation or high flow oxygen devices

7. Hospitalized, on invasive mechanical ventilation or extracorporeal membrane oxygenation

8. Death

Only patients with score 4,5 , or 6 on the 8 -point scale were admitted to the study.

Secondary endpoints included the time to clinical improvement, time to sustained recovery and time to discharge from the hospital during the 28 days after dosing. Day of recovery was defined as the first day on which the participant satisfied 1 of the following 3 categories from the 8-point ordinal scale 1) Not hospitalized, no limitations on activities.; 2) Not hospitalized, limitation on activities and/or requiring home oxygen; 3) Hospitalized, not requiring supplemental oxygen - no longer requires ongoing medical care. Time to clinical improvement required $\geq 2$ points improvement in the 8 -point ordinal scale during the 28 days after dosing. Sustained recovery required patients to be free of relapse or worsening after improvement.

The statistical design was based on approximately 330 participants per treatment arm where there would be an approximately $80 \%$ power to show a statistically significant superiority of 2 $\mathrm{mg} / \mathrm{kg}$ dose over placebo in the proportion of participants alive and free from respiratory deterioration during the 28 days after dosing at a 1-sided alpha level of 0.0125 when true 
proportion of $2 \mathrm{mg} / \mathrm{kg}$ dose is $92 \%$ and placebo is $84 \%$. The same sample size and power statement was used for the comparison between $1 \mathrm{mg} / \mathrm{kg}$ and placebo.

In addition to clinical endpoints, serum samples were collected at various times and were tested for antibody response to SARS-CoV-2 including several variants.

Enrollment began in February 2021. In July 2021, after enrolling 40 patients, it was decided to discontinue the phase 3 trial due to slower than expected enrollment and waning of the COVID19 incidence in the U.S. before the 4th wave associated with the delta variant occurred. Given the importance of the pandemic and need for more effective therapies, we analyzed the available data recognizing the sample size was underpowered to establish statistical significance. The results in these 40 patients are reported below. Data from the three cohorts remained blinded until this analysis.

\section{Clinical Results}

Forty patients were randomized to receive standard of care plus either single dose: Mupadolimab $1 \mathrm{mg} / \mathrm{kg}(\mathrm{N}=14), 2 \mathrm{mg} / \mathrm{kg}(\mathrm{N}=15)$ or placebo $(\mathrm{N}=11)$ at 8 sites (7 U.S.). The clinical characteristics are shown in Table 2. Generally, the treatment arms were balanced. Overall, the median age was 55 years and $42 \%$ were female. Presenting symptoms were typical for patients with COVID-19. Patients in the $2 \mathrm{mg} / \mathrm{kg}$ cohort had more severe disease on admission with $60 \%$ having a score of 6 points on the 8-point ordinal scale vs. $7 \%$ in the $1 \mathrm{mg} / \mathrm{kg}$ and $27 \%$ in the placebo cohorts.

No drug related adverse events were reported in the study. No severe ( $\geq$ Grade 3 ) or serious adverse events were observed in patients who received mupadolimab. Serious adverse events were reported in two patients in the placebo arm: 1 patient with acute respiratory distress syndrome and 1 patient with steroid induced psychosis.

The results for the primary and key secondary endpoints are summarized in Table 3. All endpoints trended toward more favorable outcome for mupadolimab treated patients vs. placebo. For the primary endpoint, $93.3 \%, 85.7 \%$ and $81.1 \%$ were alive and free from respiratory failure in the $2 \mathrm{mg} / \mathrm{kg}, 1 \mathrm{mg} / \mathrm{kg}$ and placebo cohorts, respectively. These differences were not statistically significant. Positive trends favoring mupadolimab also were seen for all the key secondary endpoints of time to clinical improvement, time to sustained improvement and time to discharge from the hospital. Kaplan Meier curves for these endpoints are shown in Figure 4A-4F. 


\section{Neutralizing antibody response data}

Pretreatment and day 28 serum samples were available for 26 patients: 7 , placebo; $8,1 \mathrm{mg} / \mathrm{kg}$ cohort; and 11, $2 \mathrm{mg} / \mathrm{kg}$ cohort. Antibody response to Wuhan trimeric spike protein measured by ELISA was similar between cohorts at baseline and at day 28. An assay that measures serum blocking of RBD binding to ACE2 was used to assess neutralization against Wuhan and alpha (B.1.1.7), beta (B.1.351), gamma (P.1) and delta (B.1.617.2) variants. As shown in Figure 5A, serum neutralizing titers in the $2 \mathrm{mg} / \mathrm{kg}$ cohort appeared to trend higher against Wuhan and the variants with several patients exhibiting very high titers $(\mathrm{p}=0.23$ for $2 \mathrm{mg} / \mathrm{kg}$ cohort vs placebo on delta variant). Patients in the $2 \mathrm{mg} / \mathrm{kg}$ cohort also demonstrated higher cross-reactivity with the B.1.351 and P.1 variants compared to $1 \mathrm{mg} / \mathrm{kg}$ and placebo (Figure 5B). These differences were not related to duration of illness, which was similar in all groups (Table 2). We do not have the identity of the variant infecting each patient at this time.

\section{DISCUSSION}

We have produced an anti-CD73 antibody with novel immunostimulatory properties and now report additional safety and immunologic activity in hospitalized patients with COVID-19. CD73 was originally characterized as a costimulatory molecule for $\mathrm{T}$ cells, but our previously reported results presented demonstrated that mupadolimab predominantly activates CD73 ${ }^{\text {POS }} \mathrm{B}$ cells.[17]

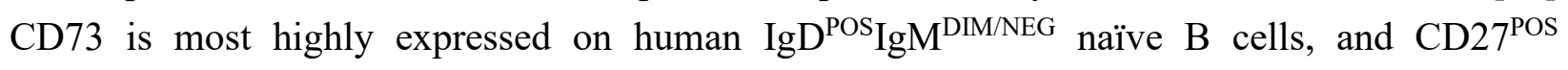
memory B cells expressing IgG or IgA.[11] Mupadolimab induces the expression of CD69, an activation marker that negatively regulates S1PR1 function, resulting in the prolonged retention of activated B cells in lymphoid organs and thymus.[26] This increased lymphoid residence time potentially provides time to complete $\mathrm{B}$ cell activation and interaction with $\mathrm{CD} 4^{\mathrm{POS}} \mathrm{T}$ follicular helper cells to shape downstream immune responses. Previous studies with mupadolimab also have shown that it induces the secretion of cytokines involved in B cell differentiation including CCL22. Liu et al. have published that CCL22 promotes efficient B cell maturation in germinal centers by increasing the interaction of B cells with $T$ follicular helper cells.[27] While B cell activation with mupadolimab is independent of adenosine blockade in vitro, the CD73 enzymatic blockade may be complementary in vivo as adenosine has been shown to restrict lymphocyte migration into lymph nodes in preclinical animal models.[28] The role of CD73 expression on cells contained in lymph nodes and in germinal centers is of potential importance.[29] Recent data shows that lymph nodes from SARS-CoV-2 infected patients lack germinal centers and would be expected to have impaired humoral immunity.[30] It is conceivable that mupadolimab restores proper immune function in these compromised germinal centers either through its action on B cells or other CD73 positive cells. 
Here we report data from a completed open label phase 1 study in hospitalized patients demonstrating that antibody titers to trimeric spike protein and to the RBD of SARS-CoV-2 with neutralizing activity, increasing within 7 days in patients treated with a single dose of mupadolimab at $0.3-5 \mathrm{mg} / \mathrm{kg}$. The doses evaluated in our study were selected because previous in vitro studies have shown that concentrations of mupadolimab exceeding $1 \mu \mathrm{g} / \mathrm{ml}$ are required for maximal B cell activation and such levels are achieved in vivo with doses of at least $1 \mathrm{mg} / \mathrm{kg}$.

Although lacking a control arm, the median time to hospital discharge was 3 days. This compares favorably to reports from other studies in comparable patient populations.[5-8, 31] Most patients with COVID-19 become seropositive for $\mathrm{IgG} / \mathrm{IgM} / \mathrm{IgA}$ within 2-3 weeks following onset of symptoms.[32] The patients in the Phase 1 trial had low levels of anti-SARS-CoV2 antibodies at the time of hospitalization despite a wide range of duration of prior symptoms from 1-21 days. The lack of response in these patients may be related to host factors reducing the ability to mount a humoral response or other unknown immunosuppressive effects of viral infection. Mupadolimab may overcome this apparent immunodeficiency as we observed robust anti-SARS-CoV-2 antibody responses induced by mupadolimab in patients with long period POS and low pre-treatment titers. The kinetics following seroconversion are still being clarified, but others have reported that antibody titers in COVID-19 patients plateau approximately 6 days after seroconversion before steadily declining in the following weeks $(\operatorname{IgM} / \operatorname{IgA})$ to months (IgG).[32] Our results show that anti-SARS-CoV2 titers continue to rise reaching a stable plateau in the weeks following treatment, possibly hinting at a more robust and durable humoral response that would theoretically improve clinical outcomes in COVID-19 patients. These effects may also serve to reduce viral transmission. In line with this idea, Chen et al. have shown that sustained antibody titers predict favorable clinical outcome in COVID-19.[33]

Based on these findings, a randomized double-blind, placebo-controlled trial was undertaken, but was discontinued early, after enrolling 40 patients, due to waning of the COVID-19 incidence in July 2021. Single injections of either $2 \mathrm{mg} / \mathrm{kg}$ or $1 \mathrm{mg} / \mathrm{kg}$ had no reported adverse events, with two serious adverse events seen in the placebo group. These adverse events consisted of acute respiratory distress syndrome and steroid psychosis, both reported as disease related. Although stopped prematurely and therefore underpowered to show statistical significance, the primary and secondary endpoints all trended towards favoring the treatment cohorts. The largest impact on the primary endpoint was seen in the $2 \mathrm{mg} / \mathrm{kg}$ cohort despite this group having patients with more advanced disease on enrollment. In a phase 3 study in hospitalized patients using convalescent plasma, the median time to discharge was 13 days.[31] In a recent Phase 3 trial in hospitalized patients with COVID-19 treated with tofacitinib, the proportion of patients progressing to respiratory failure or death was $18 \%$ for tofacitinib and $29 \%$ in the placebo group. 
Further studies will be required to establish the safety and efficacy of mupadolimab. We believe the results from our studies will encourage additional clinical testing in COVID-19. The effects seen with relatively low doses of mupadolimab indicate that alternative routes of delivery such as subcutaneous or intramuscular administration are feasible. Such low doses and routes of administration may make this treatment feasible in the outpatient setting or possibly delivered as an adjuvant for vaccination of healthy subjects.

We evaluated antibody responses to SARS-CoV-2 spike protein in our treated patients. Serum binding to Wuhan trimeric spike protein reached high titers in ELISA in all our treated patients. In the Phase 3 trial, we tested serum for neutralization activity using a blocking assay that has been shown to strongly correlate with viral neutralization. Patients in this trial were enrolled prior to the emergence of the delta variant in the U.S. Patients receiving $2 \mathrm{mg} / \mathrm{kg}$ of mupadolimab demonstrated a trend toward higher titers against Wuhan and each of the variants. These results are consistent with the proposed mechanism of B cell activation and induction of broadly cross-reactive antibodies. Such responses could be protective against future infection with other variants. In addition to a potential role in stimulating humoral immunity, B cells are known to be important in antigen presentation and induction of $\mathrm{T}$ cell immunity.[34]

Multiple viral and mRNA-based vaccines in development have demonstrated the potential to induce humoral and cellular responses to SARS-CoV-2 antigens in vaccinated normal subjects.[35, 36] While encouraging, diminishing antibody titers, especially to variants, have necessitated booster vaccinations. [37, 38] Mupadolimab is being developed as a therapeutic, but it is important to note that it could potentially be used as a vaccine adjuvant to boost the titer, diversity, and duration of antibody responses and potentiate the development of long term immunity by generating memory $\mathrm{B}$ and effector $\mathrm{T}$ cells. This combination approach may be useful to enable successful immunization with a single vaccination and particularly effective in vulnerable populations such as immunosuppressed and elderly patients who do not typically respond well to vaccines.

Absent a larger randomized trial, we are currently unable to conclude that the effects observed thus far in treated COVID-19 patients are directly attributable to mupadolimab. Our current results demonstrate an atypically robust and durable antibody response following mupadolimab treatment, but we cannot exclude the possibility that these responses would have developed naturally. Moreover, multiple confounding factors including the variability in patient responses, clinical setting, and lack of standardized testing methods complicate comparisons to other therapeutics in development. Nonetheless, these encouraging early results are in line with our 
medRxiv preprint doi: https://doi.org/10.1101/2021.09.13.21263406; this version posted September 28, 2021. The copyright holder for this

It is made available under a CC-BY-NC-ND 4.0 International license .

hypothesized biological mechanism. If confirmed, mupadolimab could be useful for the treatment or prevention of other viral infections and future pandemics.

\section{MATERIALS \& METHODS}

Preclinical mouse immunization model

NSG-SGM3 mice (Jackson Laboratories, stock \#013062) were immunized with an emulsion of 50 ug full length spike protein from SARS-CoV-2 (ABClonal) and Freund's Incomplete Adjuvant (Sigma) subcutaneously on both the left and right flank ( $25 \mu \mathrm{g} / \mathrm{side})$. Mice were then randomized into two treatment groups: half the animals were dosed daily (i.p.) with $10 \mathrm{mg} / \mathrm{kg}$ mupadolimab, and half the animals were dosed daily with $10 \mathrm{mg} / \mathrm{kg} \mathrm{hIgG1}$ (BioXCell). Animals were cheek bled on days 1 (pre-bleed), 4, 8, 11 and 15 to assess anti-spike or anti-nucleocapsid (as a negative control) antibody production over time by ELISA.

\section{Anti-SARS-CoV-2 antibody ELISA assays}

ELISA was performed to measure the IgG and IgM to the receptor-binding domain (RBD) of the spike protein, full-length spike trimer of the SARS-CoV-2 virus. Purified recombinant SARSCoV-2 RBD and full-length spike protein were obtained from Lake Pharma. ELISA plates were coated with RBD or spike protein $\left(2 \mu \mathrm{g} / \mathrm{mL}\right.$ in PBS) overnight at $4^{\circ} \mathrm{C}$ then blocked with $3 \%$ BSA in PBS for $1 \mathrm{hr}$. at room temperature (RT) after three washes with PBST. Serial dilutions of serum were prepared in PBST containing 1\% BSA, then dispensed to the wells of the coated microtiter plate and incubated for $2 \mathrm{hr}$ at RT. After three washes, the bound antibody was detected using anti-human IgG-horseradish peroxidase (HRP) conjugated secondary antibody (1:3000, Sigma-Aldrich, A0170) or anti-human IgM HPR secondary antibody (1:3000, SigmaAldrich, A0420). After three washes, the reaction was developed by the addition of the substrate o-phenylenediamine dihydrochloride (SigmaFast OPD) and stopped by $\mathrm{HCl}(2 \mathrm{M})$. The absorbance at $490 \mathrm{~nm}$ (OD490) was measured using an Envision plate reader (PerkinElmer). Recovered COVID-19 patient serum was obtained from Sanguine Biosciences from recovered patients confirmed to have had a COVID-19 $\mathrm{PCR}+$ result. All serum samples were treated to inactivate infectious virus by incubation at $56^{\circ} \mathrm{C}$ for 30 mins. Healthy volunteer serum samples obtained from Stanford Blood Center during 2018 served as negative control. The titer cutoff value at OD490 is the mean plus 3 standard deviations of the negative controls. The endpoint titer is reported as the highest dilution of at least two before the OD490 decreases below the cutoff value. Data were analyzed using GraphPad Prism 7. 


\section{Neutralizing Antibody ELISA}

Neutralizing antibody titers in a biochemical ELISA format were measured using the MSD platform. Briefly, human sera were prepared using a 3-fold serial dilution starting at 1:30. The diluted sera $(25 \mu \mathrm{L})$ was transferred to the wells of a blocked multiplex plate precoated with wild type and variant spike proteins (MSD) and incubated for $60 \mathrm{~min}$ at room temperature. The sera was diluted a further 2-fold by addition of an equal volume of sulfotagged ACE2 (MSD) and the mixture incubated for 60 min at room temperature. Unbound sulfotagged ACE2 was removed by washing the plate three times with $150 \mu \mathrm{L}$ of phosphate-buffered saline, $0.05 \%$ Tween-20. Bound ACE2 was detected by addition of $150 \mu \mathrm{L}$ of $1 \mathrm{X}$ read buffer (MSD) and chemiluminescence read using a Quickplex SQ 120 plate reader (MSD). ID50 values were obtained by fitting the response data to a four-parameter logistic equation using GraphPad Prism version 8.4.3 for Windows, GraphPad Software, San Diego, California USA.

\section{$\underline{\text { Viral neutralization assays }}$}

SARS-CoV-2 spike pseudotyped lentivirus were produced with the Wuhan-Hu-1 (wild type), B.1.1.7 or B.1.351 variant spike as the envelope glycoprotein and the firefly luciferase gene as a reporter (BPS Bioscience). Neutralization activity was determined using heat inactivated serum $\left(56^{\circ} \mathrm{C}, 30 \mathrm{~min}\right)$ mixed with pseudovirus before addition to HEK293T-hACE2 cells. Luciferase activity was measured seventy-two hours after transduction and SARS-CoV-2 neutralization titers were defined as the reciprocal dilution yielding a $50 \%$ reduction in signal relative to the average of uninhibited control wells.

\section{ACKNOWLEDGEMMENTS}

The authors wish to thank hospital staff caring for these patients, and the patients and their families for participating in these studies.

\section{FIGURE TITLES \& LEGENDS}

\section{Fig 1. Mupadolimab Elicits Antigen Specific Immunity in a Preclinical Animal Model.}

NSG-SGM3 mice were immunized with an emulsion of $50 \mu \mathrm{g}$ full length spike protein from SARS-CoV-2 plus Freund's incomplete adjuvant (subcutaneously on both the left and right flank ( $25 \mu \mathrm{g} / \mathrm{side}$ ). Mice were then randomized into two treatment groups: half the animals were dosed daily (i.p.) with $10 \mathrm{mg} / \mathrm{kg}$ mupadolimab, and half the animals were dosed daily with $10 \mathrm{mg} / \mathrm{kg}$ hIgG1. Animals were cheek bled on days 1 (pre-treatment), 4, 8, 11, and 15 to assess anti-Spike (A) or anti-nucleocapsid (B, as a negative control) antibody production over time by ELISA. 
medRxiv preprint doi: https://doi.org/10.1101/2021.09.13.21263406; this version posted September 28, 2021. The copyright holder for this preprint (which was not certified by peer review) is the author/funder, who has granted medRxiv a license to display the preprint in perpetuity.

It is made available under a CC-BY-NC-ND 4.0 International license .

Fig 2. Anti-SARS-CoV-2 antibody and cellular responses in COVID-19 patients treated with mupadolimab.

A, B) Patients received a $0.3,1.0,3.0$ or $5.0 \mathrm{mg} / \mathrm{kg}$ single dose of mupadolimab and endpoint IgG titers to TS (A) and RBD (B) were measured at pre-treatment and at day 28, 56, 84, and 168. C) Longitudinal analyses of IgG against SARS-CoV-2 in mupadolimab treated subject. The green line is a smoothing spline fit. Each black line represents an individual patient. D, E) Patients received a $0.3,1.0,3.0$ or $5.0 \mathrm{mg} / \mathrm{kg}$ single dose of mupadolimab and endpoint $\operatorname{IgM}$ titers to TS (D) and RBD (E) were measured at pre-treatment and at day 28, 56, 84, and 168. F) Frequency of circulating memory B cells $\left(\mathrm{CD} 19^{\mathrm{POS}} \mathrm{IgD}^{\mathrm{NEG}} \mathrm{CD} 27^{\mathrm{POS}}\right)$ within $\mathrm{CD} 19^{\mathrm{POS}}$ gate at baseline and after treatment in patients treated with $0.3 \mathrm{mg} / \mathrm{kg}$ mupadolimab compared to $\geq 1.0$ $\mathrm{mg} / \mathrm{kg}$. Data are shown as box and whisker plot with geometric mean and interquartile range. Each dot represents a patient. Also shown are titers from convalescent patient serum obtained 46 weeks after POS.

Fig 3. Sera from mupadolimab treated subjects neutralize wild type SARS-CoV-2 and spike variants.

A) Titers required to achieve 50\% neutralization (ID50) of infectivity with wild type SARS-CoV-

2 pseudovirus. B) Neutralization (ID 50 ) of infectivity with spike variant pseudovirus. Each symbol represents an individual patient. UK - United Kingdom, SA - South Africa.

Fig 4. Kaplan-Meier plots of time to events for secondary endpoints compared to placebo. A-F

Fig 5. ACE2 / RBD blocking assay.

A) ID50 for serum samples assayed against wild type (Wuhan) and variants using ACE2-RBD

blocking assay. B) As in A, with data showing reactivity for each patient against variants.

Table 1: Baseline characteristics of COVID-19 patients treated in the Phase 1.

CAD - coronary artery disease, CKD - chronic kidney disease, COPD - chronic obstructive pulmonary disease, DM - diabetes, HTN - hypertension

Table 2: Baseline characteristics of enrolled COVID-19 patients treated in the Phase 1.

Baseline patient characteristics are shown. Comorbidities include: diabetes, hypertension, asthma, obesity, cancer, etc. BMI - body mass index

Table 3: Summary of Efficacy Endpoints.

CI - confidence interval 


\section{REFERENCES:}

1. Wu F, Zhao S, Yu B, Chen YM, Wang W, Song ZG, et al. A new coronavirus associated with human respiratory disease in China. Nature 2020; 579:265-9.

2. Zhou P, Yang X-L, Wang X-G, Hu B, Zhang L, Zhang W, et al. A pneumonia outbreak associated with a new coronavirus of probable bat origin. Nature 2020; 579:270-3.

3. Huang C, Wang Y, Li X, Ren L, Zhao J, Hu Y, et al. Clinical features of patients infected with 2019 novel coronavirus in Wuhan, China. Lancet 2020; 395:497-506.

4. Corey L, Beyrer C, Cohen MS, Michael NL, Bedford T, Rolland M. SARS-CoV-2 variants in patients with immunosuppression. The New England journal of medicine 2021; 385:562-566.

5. Group RC, Horby P, Lim WS, Emberson JR, Mafham M, Bell JL, et al. Dexamethasone in hospitalized patients with Covid-19. The New England journal of medicine 2021; 384:693-704.

6. Salama C, Han J, Yau L, Reiss WG, Kramer B, Neidhart JD, et al. Tocilizumab in patients hospitalized with Covid-19 pneumonia. The New England journal of medicine 2021; 384:20-30.

7. Kalil AC, Patterson TF, Mehta AK, Tomashek KM, Wolfe CR, Ghazaryan V, et al. Baricitinib plus remdesivir for hospitalized adults with Covid-19. The New England journal of medicine 2021; 384:795-807.

8. Guimarães PO, Quirk D, Furtado RH, Maia LN, Saraiva JF, Antunes MO, et al. Tofacitinib in patients hospitalized with Covid-19 pneumonia. The New England journal of medicine 2021 ; 385:406-415.

9. Thomson LF, Ruedi JM, Glass A, Moldenhauer G, Moller P, Low MG, et al. Production and characterization of monoclonal antibodies to the glycosyl phosphatidylinositolanchored lymphocyte differentiation antigen ecto-5'-nucleotidase (CD73). Tissue Antigens 1990; 35:9-19.

10. Resta R, Yamashita Y, Thompson LF. Ecto-enzyme and signaling functions of lymphocyte CD73. Immunol Rev 1998; 161:95-109.

11. Glass DR, Tsai AG, Oliveria JP, Hartmann FJ, Kimmey SC, Calderon AA, et al. An Integrated Multi-omic Single-Cell Atlas of Human B Cell Identity. Immunity 2020; 53:217-32 e5.

12. Thompson LF, Ruedi JM, O'Connor RD, Bastian JF. Ecto-5'-nucleotidase expression during human B cell development. An explanation for the heterogeneity in B lymphocyte ecto-5'-nucleotidase activity in patients with hypogammaglobulinemia. J Immunol 1986; 137:2496-500. 
13. Schena F, Volpi S, Faliti CE, Penco F, Santi S, Proietti M, et al. Dependence of immunoglobulin class switch recombination in B cells on vesicular release of ATP and CD73 ectonucleotidase activity. Cell Rep 2013; 3:1824-31.

14. Resta R, Thompson LF. T cell signalling through CD73. Cell Signal 1997; 9:131-9.

15. Burger RM, Lowenstein JM. 5'-Nucleotidase from smooth muscle of small intestine and from brain. Inhibition of nucleotides. Biochemistry 1975; 14:2362-6.

16. Luke JJ, Powderly JD, Merchan JR, Barve MA, Hotson AN, Mobasher M, et al. Immunobiology, preliminary safety, and efficacy of CPI-006, an anti-CD73 antibody with immune modulating activity, in a phase 1 trial in advanced cancers. Journal of Clinical Oncology 2019; 37:2505-.

17. Willingham S, Criner G, Hill C, Hu S, Rudnick J, Daine-Matsuoka B, et al. Characterization and Phase 1 trial of a B cell activating anti-CD73 antibody for the immunotherapy of COVID-19. medRxiv 2020; https://doi.org/10.1101/2020.09.10.20191486.

18. Ishikawa F, Yasukawa M, Lyons B, Yoshida S, Miyamoto T, Yoshimoto G, et al. Development of functional human blood and immune systems in NOD/SCID/IL2 receptor \{gamma\} chain(null) mice. Blood 2005; 106:1565-73.

19. Ippolito GC, Hoi KH, Reddy ST, Carroll SM, Ge X, Rogosch T, et al. Antibody repertoires in humanized NOD-scid-IL2Rgamma(null) mice and human B cells reveals human-like diversification and tolerance checkpoints in the mouse. PloS one 2012; 7:e35497.

20. Bastard P, Rosen LB, Zhang Q, Michailidis E, Hoffmann HH, Zhang Y, et al. Autoantibodies against type I IFNs in patients with life-threatening COVID-19. Science $2020 ; 370$.

21. Iyer AS, Jones FK, Nodoushani A, Kelly M, Becker M, Slater D, et al. Persistence and decay of human antibody responses to the receptor binding domain of SARS-CoV-2 spike protein in COVID-19 patients. Sci Immunol 2020; 5.

22. Seow J, Graham C, Merrick B, Acors S, Pickering S, Steel KJA, et al. Longitudinal observation and decline of neutralizing antibody responses in the three months following SARS-CoV-2 infection in humans. Nat Microbiol 2020; 5:1598-607.

23. $\mathrm{Ku} \mathrm{Z}$, Xie X, Davidson E, Ye X, Su H, Menachery VD, et al. Molecular determinants and mechanism for antibody cocktail preventing SARS-CoV-2 escape. Nature communications $2021 ; 12: 469$.

24. Baum A, Fulton BO, Wloga E, Copin R, Pascal KE, Russo V, et al. Antibody cocktail to SARS-CoV-2 spike protein prevents rapid mutational escape seen with individual antibodies. Science 2020; 369:1014-8. 
25. Yi C, Sun X, Ye J, Ding L, Liu M, Yang Z, et al. Key residues of the receptor binding motif in the spike protein of SARS-CoV-2 that interact with ACE2 and neutralizing antibodies. Cellular \& Molecular Immunology 2020; 17:621-30.

26. Shiow LR, Rosen DB, Brdickova N, Xu Y, An J, Lanier LL, et al. CD69 acts downstream of interferon-alpha/beta to inhibit S1P1 and lymphocyte egress from lymphoid organs. Nature 2006; 440:540-4.

27. Liu B, Lin Y, Yan J, Yao J, Liu D, Ma W, et al. Affinity-coupled CCL22 promotes positive selection in germinal centres. Nature 2021; 592:133-7.

28. Takedachi M, Qu D, Ebisuno Y, Oohara H, Joachims ML, McGee ST, et al. CD73generated adenosine restricts lymphocyte migration into draining lymph nodes. Journal of immunology 2008; 180:6288-96.

29. Conter LJ, Song E, Shlomchik MJ, Tomayko MM. CD73 expression is dynamically regulated in the germinal center and bone marrow plasma cells are diminished in its absence. PloS one 2014; 9:e92009.

30. Kaneko N, Kuo HH, Boucau J, Farmer JR, Allard-Chamard H, Mahajan VS, et al. Loss of Bcl-6-Expressing T Follicular Helper Cells and Germinal Centers in COVID-19. Cell 2020; 183:143-57 e13.

31. Simonovich VA, Burgos Pratx LD, Scibona P, Beruto MV, Vallone MG, Vazquez C, et al. A Randomized Trial of Convalescent Plasma in Covid-19 Severe Pneumonia. The New England journal of medicine 2021; 384:619-29.

32. Long QX, Liu BZ, Deng HJ, Wu GC, Deng K, Chen YK, et al. Antibody responses to SARS-CoV-2 in patients with COVID-19. Nat Med 2020; 26:845-8.

33. Chen Y, Zuiani A, Fischinger S, Mullur J, Atyeo C, Travers M, et al. Quick COVID-19 Healers Sustain Anti-SARS-CoV-2 Antibody Production. Cell 2020; 183:1496-507 e16.

34. Wennhold K, Thelen M, Lehmann J, Schran S, Preugszat E, Garcia-Marquez M, et al. CD86+ antigen-presenting B cells are increased in cancer, localize in tertiary lymphoid structures, and induce specific T-cell responses. Cancer Immunol Res. 2021; 9:10981108.

35. Jackson LA, Anderson EJ, Rouphael NG, Roberts PC, Makhene M, Coler RN, et al. An mRNA Vaccine against SARS-CoV-2 - Preliminary Report. The New England journal of medicine 2020.

36. Folegatti PM, Ewer KJ, Aley PK, Angus B, Becker S, Belij-Rammerstorfer S, et al. Safety and immunogenicity of the ChAdOx1 nCoV-19 vaccine against SARS-CoV-2: a preliminary report of a phase $1 / 2$, single-blind, randomised controlled trial. Lancet 2020; 396:467-78. 
medRxiv preprint doi: https://doi.org/10.1101/2021.09.13.21263406; this version posted September 28, 2021. The copyright holder for this preprint (which was not certified by peer review) is the author/funder, who has granted medRxiv a license to display the preprint in perpetuity.

It is made available under a CC-BY-NC-ND 4.0 International license .

37. Liu Y, Liu J, Xia H, Zhang X, Fontes-Garfias CR, Swanson KA, et al. Neutralizing activity of BNT162b2-elicited serum. The New England journal of medicine 2021; 384:1466-1468.

38. Wu K, Werner AP, Koch M, Choi A, Narayanan E, Stewart-Jones GBE, et al. Serum neutralizing activity elicited by mRNA-1273 vaccine. The New England journal of medicine 2021; 384:1468-1470. 
medRxiv preprint doi: https://doi.org/10.1101/2021.09.13.21263406; this version posted September 28, 2021. The copyright holder for this - preprint (which was not certified by peer review) is the author/funder, who has granted medRxiv a license to display the preprint in perpetuity Figure 1 It is made available under a CC-BY-NC-ND 4.0 International license .

A

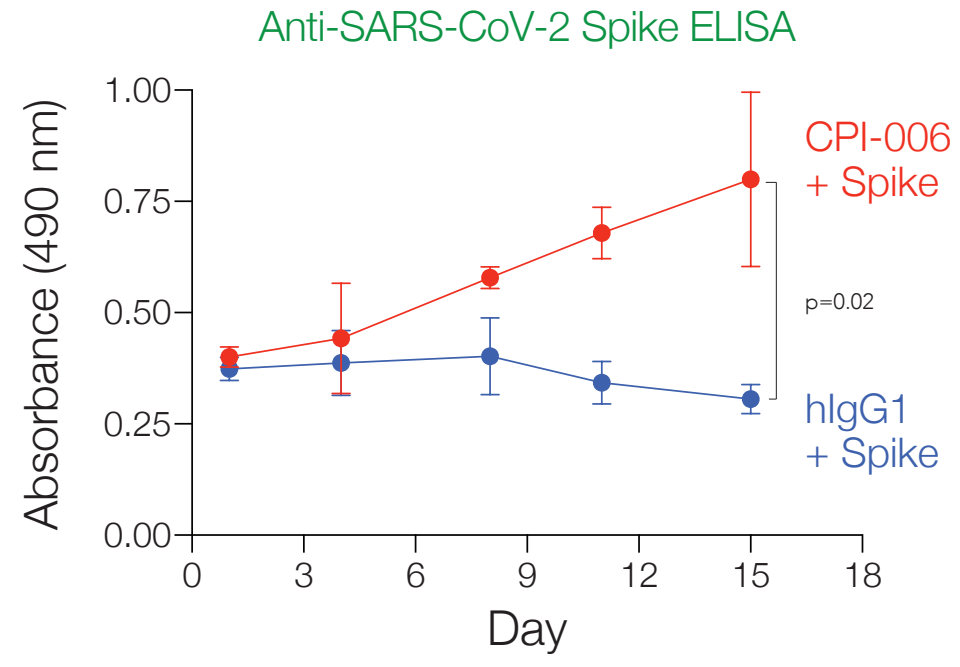

\section{B}

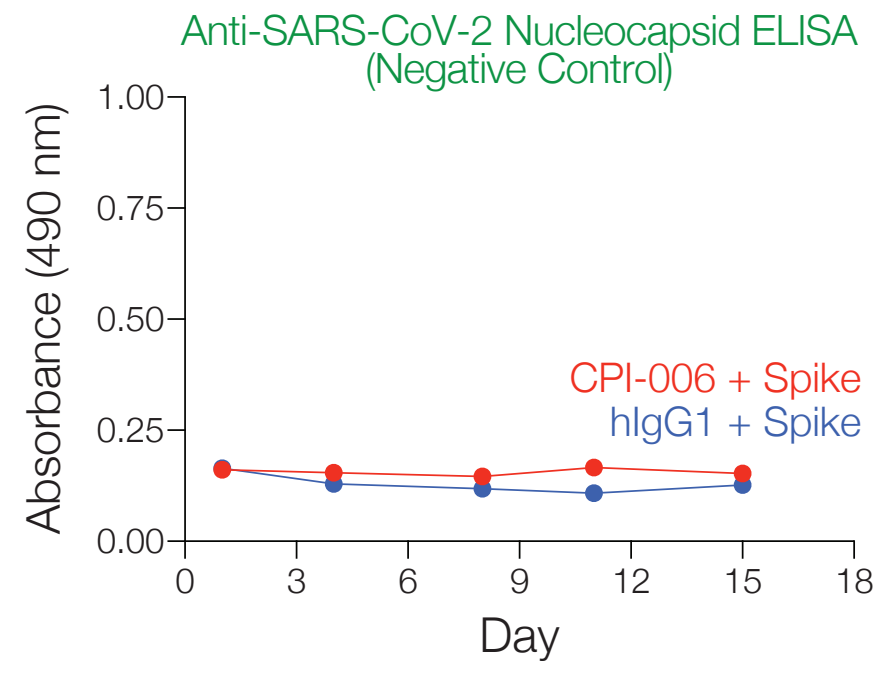


medRxiv preprint doi: https://doi.org/10.1101/2021.09.13.21263406; this version posted September 28, 2021. The copyright holder for this - preprint (which was not certified by peer review) is the author/funder, who has granted medRxiv a license to display the preprint in perpetuity. Figure 2

A

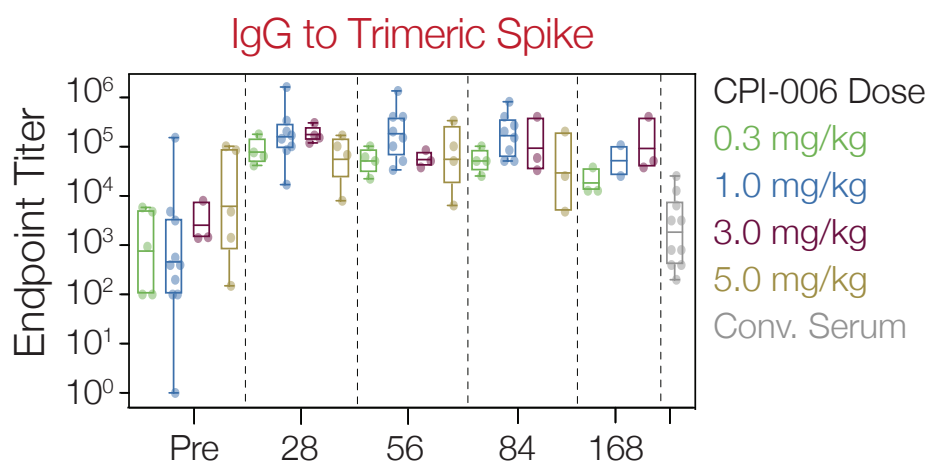

Days After CPI-006 Treatment

C

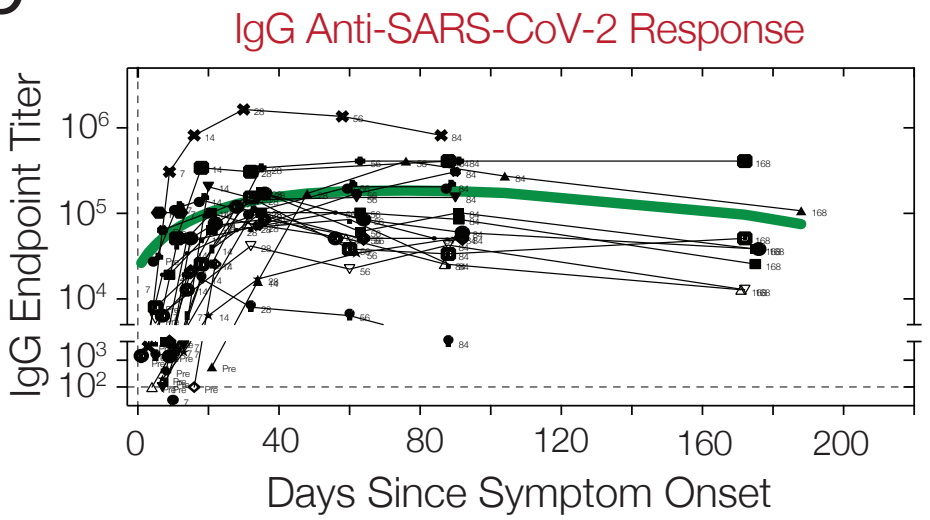

E

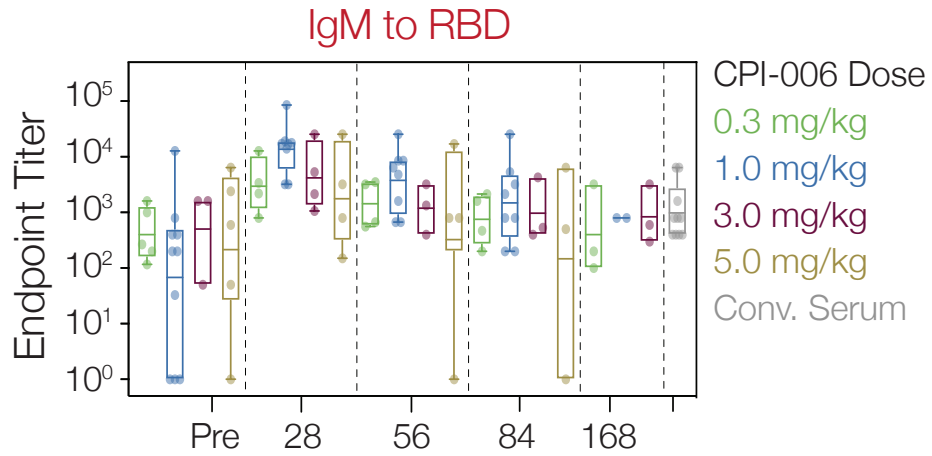

Days After CPI-006 Treatment
B

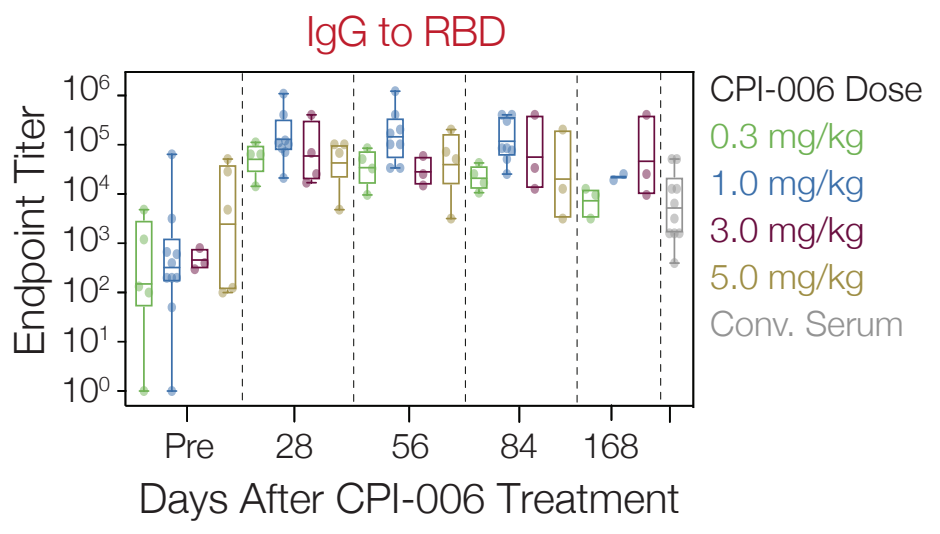

$D$

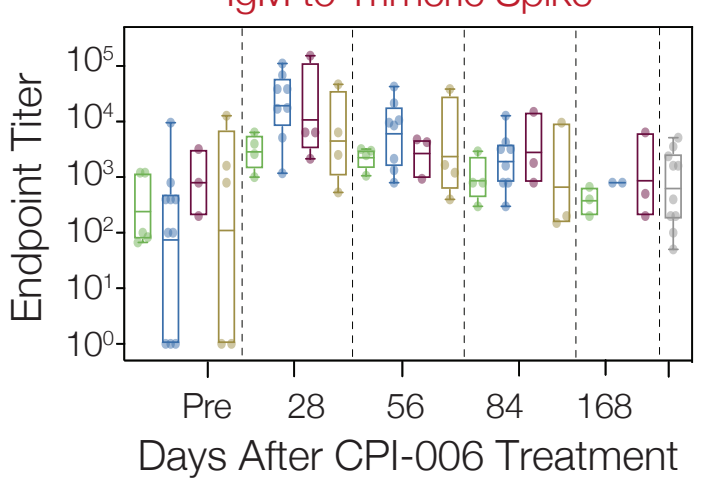

CPI-006 Dose

$0.3 \mathrm{mg} / \mathrm{kg}$

$1.0 \mathrm{mg} / \mathrm{kg}$

$3.0 \mathrm{mg} / \mathrm{kg}$

$5.0 \mathrm{mg} / \mathrm{kg}$

Conv. Serum

F

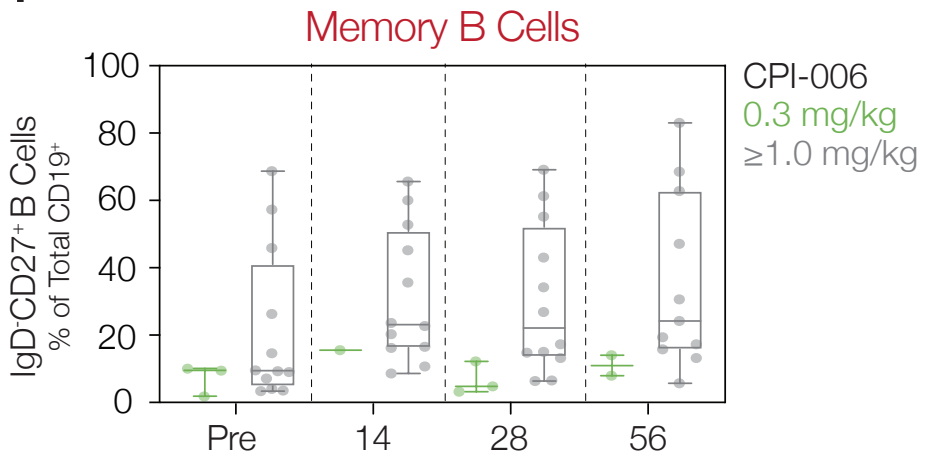

Days After CPI-006 Treatment 
medRxiv preprint doi: https://doi.org/10.1101/2021.09.13.21263406; this version posted September 28, 2021. The copyright holder for this preprint (which was not certified by peer review) is the author/funder, who has granted medRxiv a license to display the preprint in perpetuity.

Figure 3

It is made available under a CC-BY-NC-ND 4.0 International license .

A

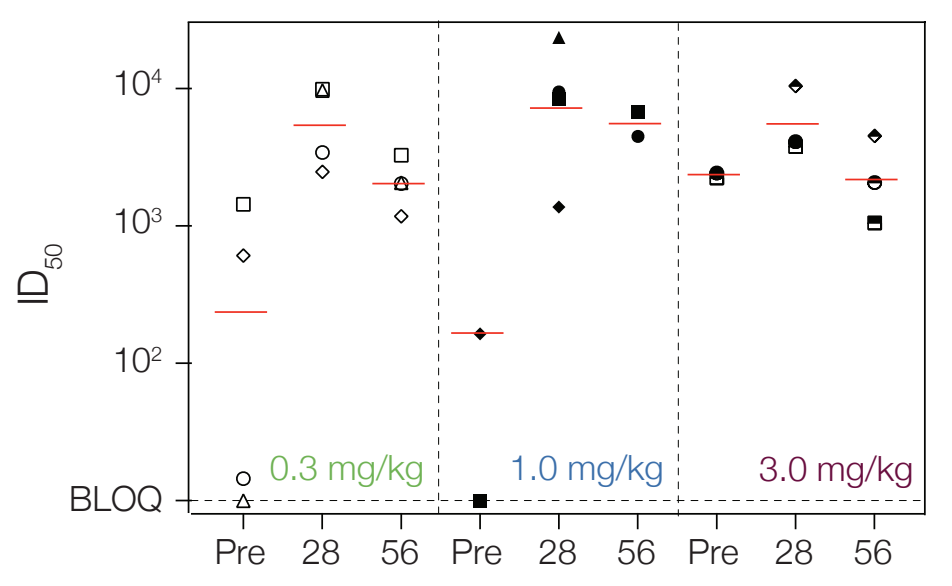

Days After CPI-006 Treatment
B

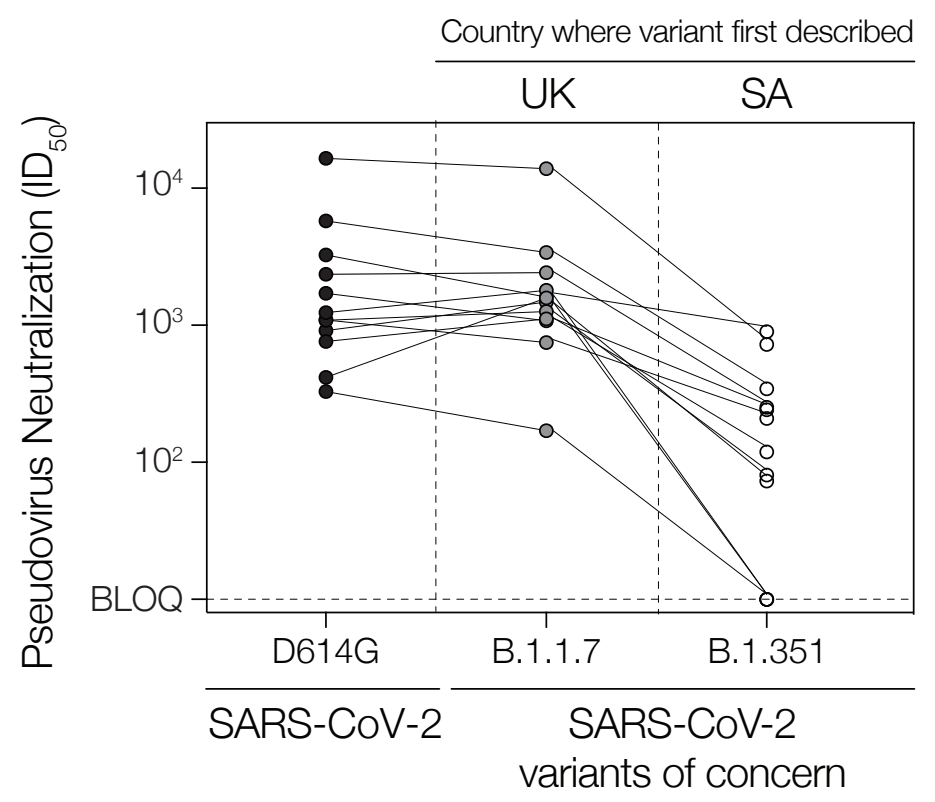


medRxiv preprint doi: https://doi.org/10.1101/2021.09.13.21263406; this version posted September 28, 2021. The copyright holder for this preprint (which was not certified by peer review) is the author/funder, who has granted medRxiv a license to display the preprint in perpetuity. Figure 4

A Time to $\geq 2$ Points Improvement in the 8-Point Ordinal Scale - Mupadolimab $2 \mathrm{mg} / \mathrm{kg}+\mathrm{SOC}$ vs Placebo + SOC

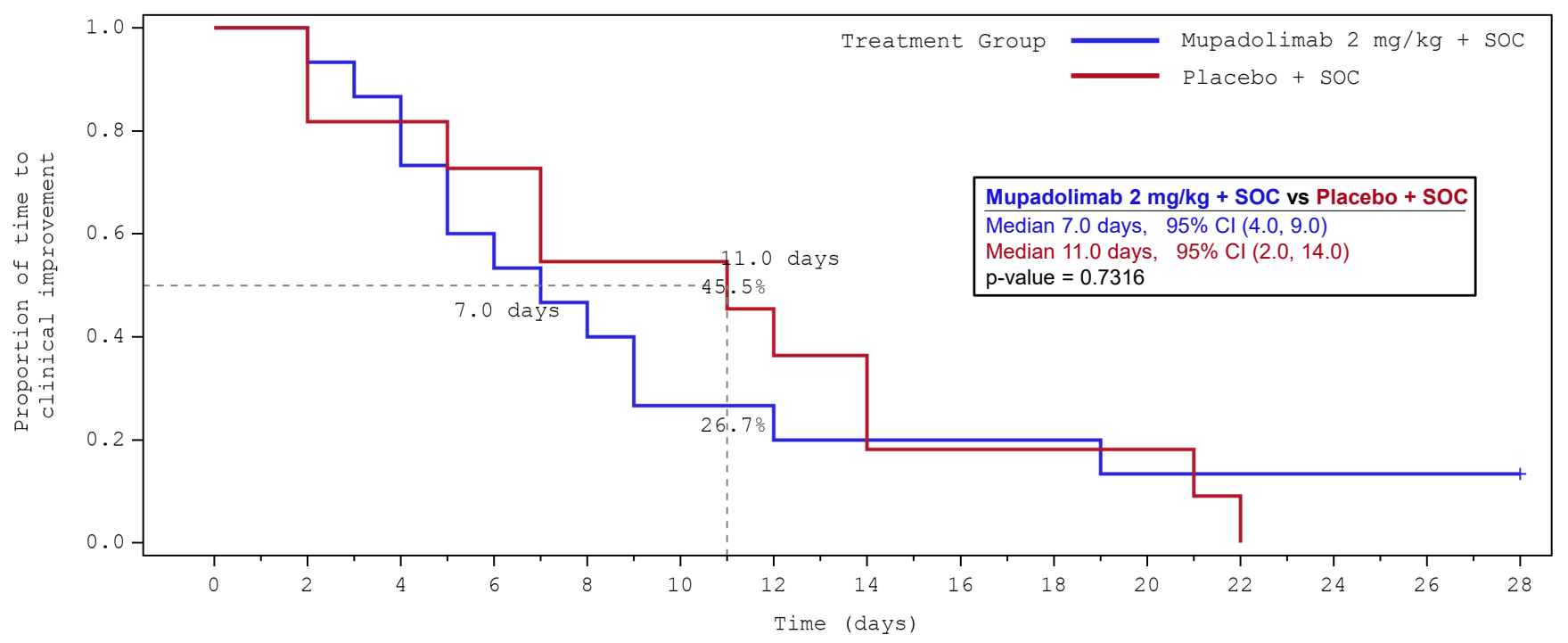

B

Time to $\geq 2$ Points Improvement in the 8-Point Ordinal Scale - Mupadolimab $1 \mathrm{mg} / \mathrm{kg}+$ SOC vs Placebo + SOC

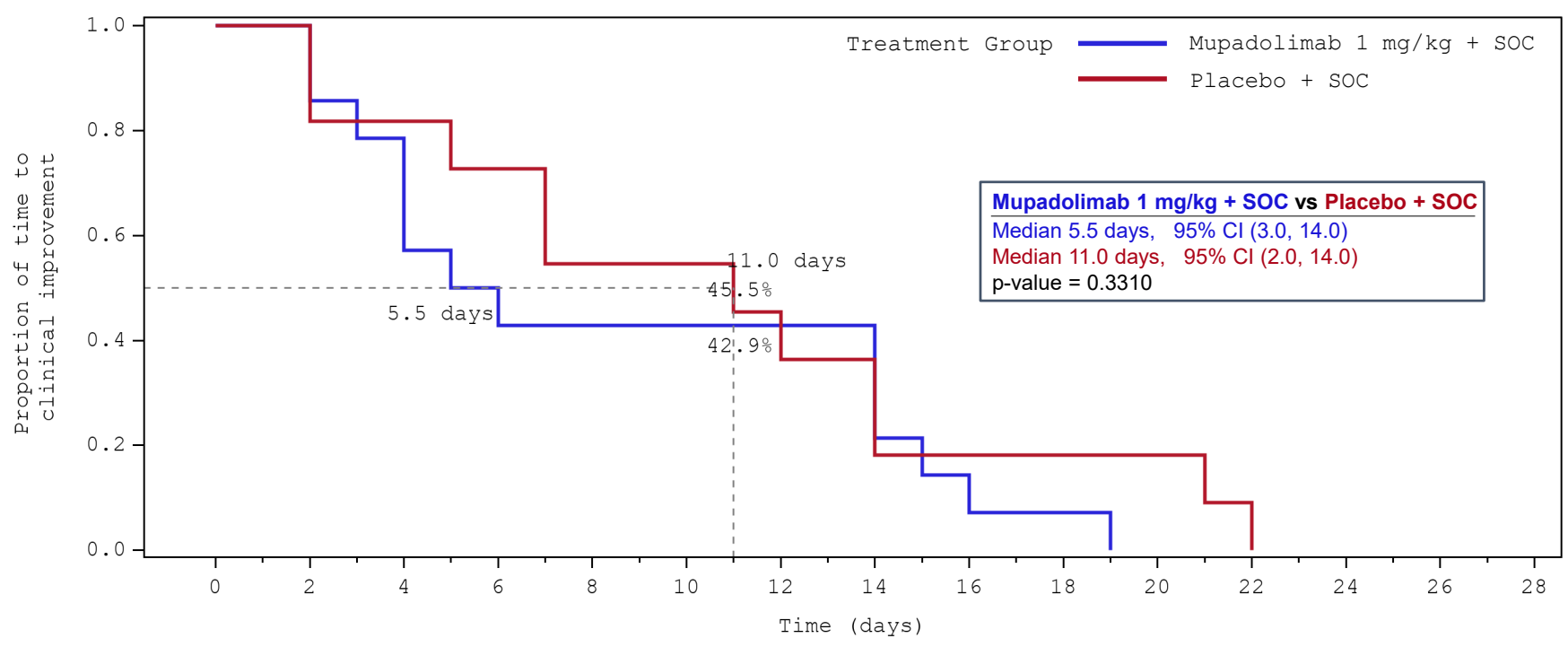


medRxiv preprint doi: https://doi.org/10.1101/2021.09.13.21263406; this version posted September 28, 2021. The copyright holder for this preprint (which was not certified by peer review) is the author/funder, who has granted medRxiv a license to display the preprint in perpetuity. Figure 4

C

Time to improve to and retained at Category 1, 2, or 3 in the 8-Point Ordinal Scale - Mupadolimab $2 \mathrm{mg} / \mathrm{kg}+\mathrm{SOC}$ vs Placebo $+\mathrm{SOC}$

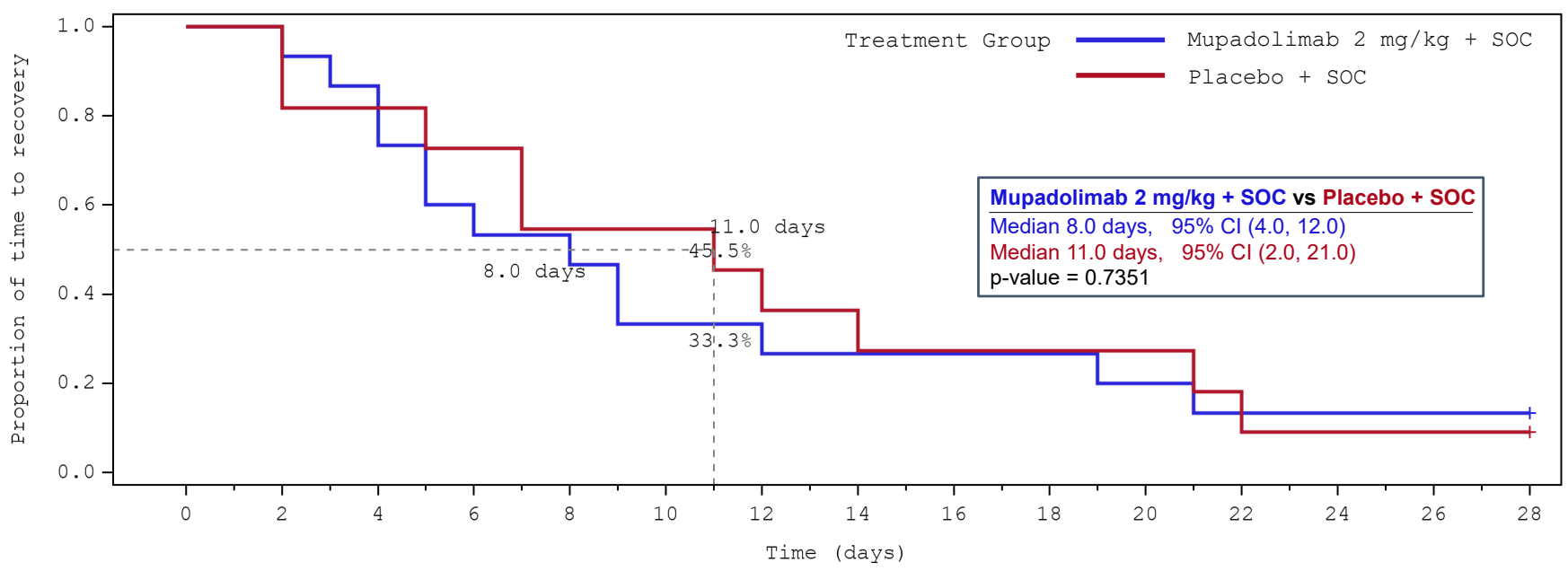

Time to improve to and retained at Category 1, 2, or 3 in the 8-Point Ordinal Scale - Mupadolimab $1 \mathrm{mg} / \mathrm{kg}+\mathrm{SOC}$ vs Placebo $+\mathrm{SOC}$

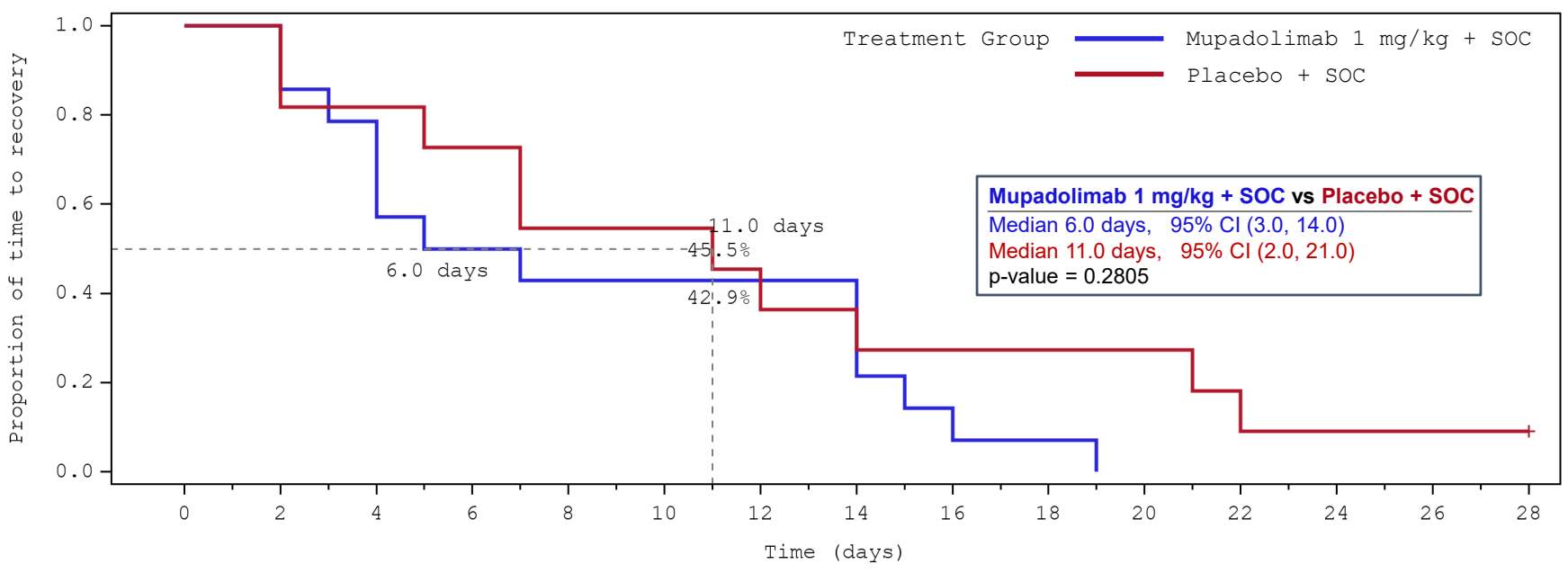


medRxiv preprint doi: https://doi.org/10.1101/2021.09.13.21263406; this version posted September 28, 2021. The copyright holder for this preprint (which was not certified by peer review) is the author/funder, who has granted medRxiv a license to display the preprint in perpetuity.

Figure 4

It is made available under a CC-BY-NC-ND 4.0 International license .

E Time to Discharge from Hospital - Mupadolimab $2 \mathrm{mg} / \mathrm{kg}+\mathrm{SOC}$ vs Placebo + SOC

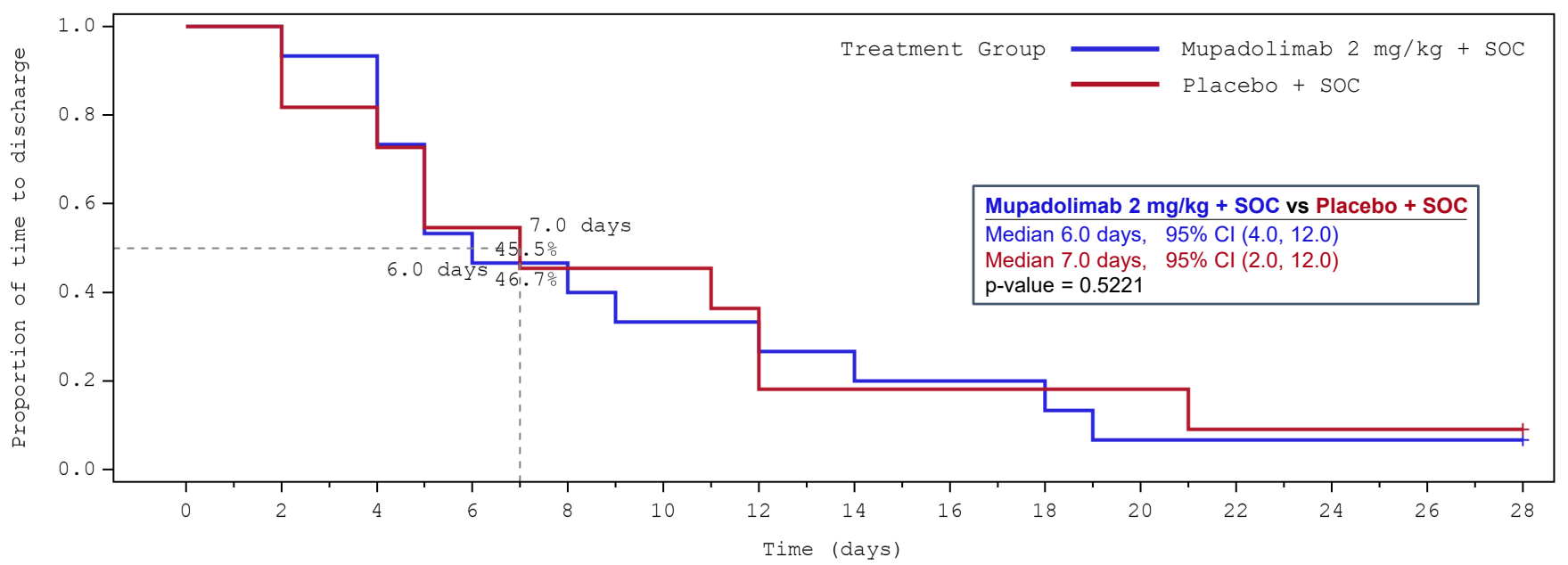

F Time to Discharge from Hospital - Mupadolimab $1 \mathrm{mg} / \mathrm{kg}+\mathrm{SOC}$ vs Placebo + SOC

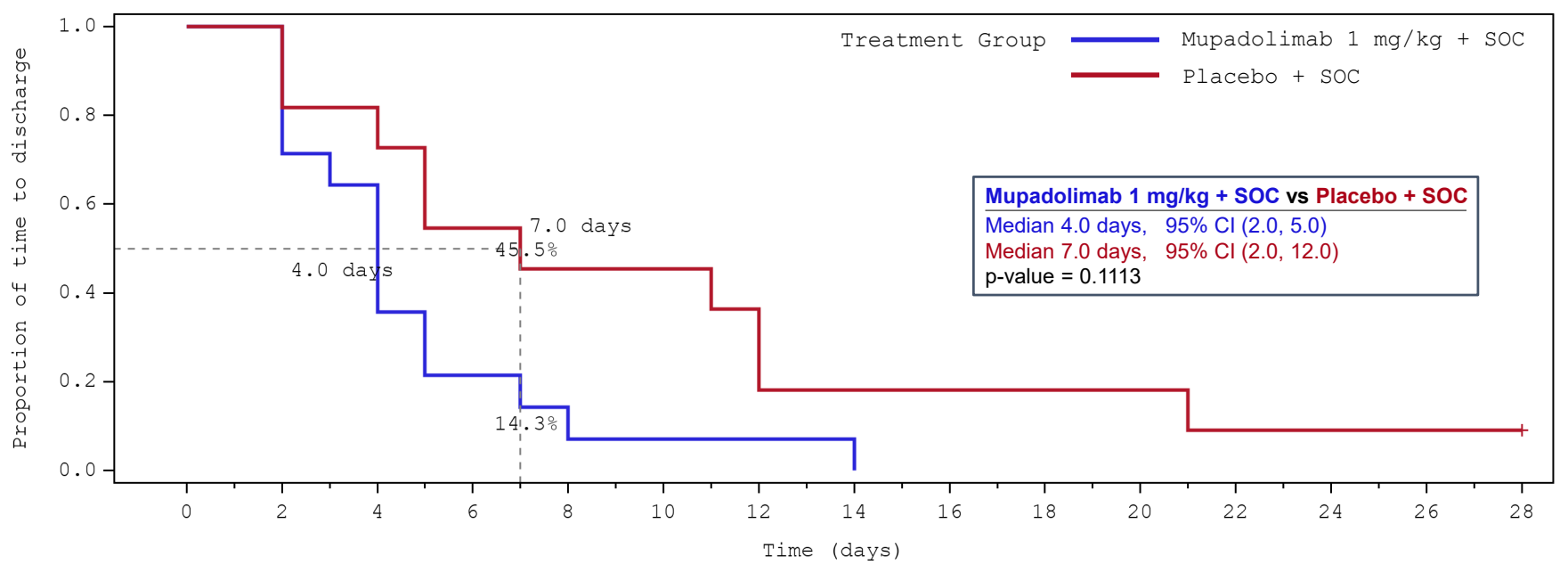


medRxiv preprint doi: https://doi.org/10.1101/2021.09.13.21263406; this version posted September 28,2021 . The copyright holder for this
preprint (which was not certified by peer review) is the author/funder, who has granted medRxiv a license to display the preprint in perpetuity.

Figure 5

It is made available under a CC-BY-NC-ND 4.0 International license .

A

Placebo cohort

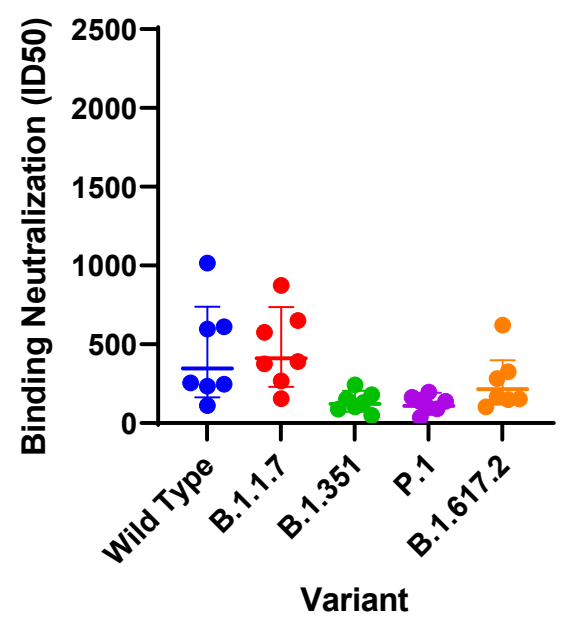

B

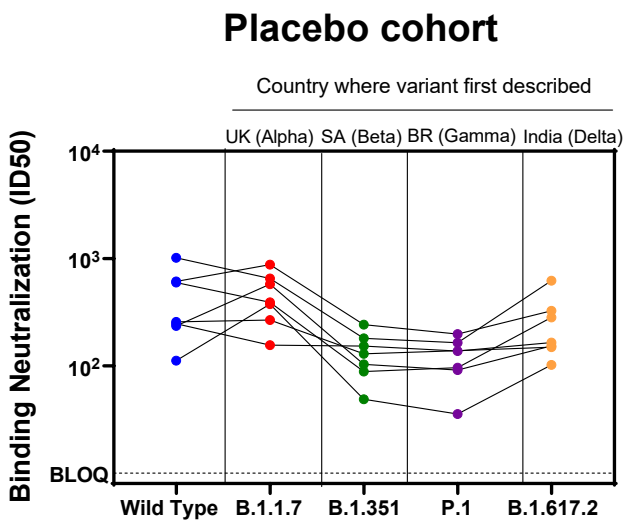

$1 \mathrm{mg} / \mathrm{kg}$ cohort

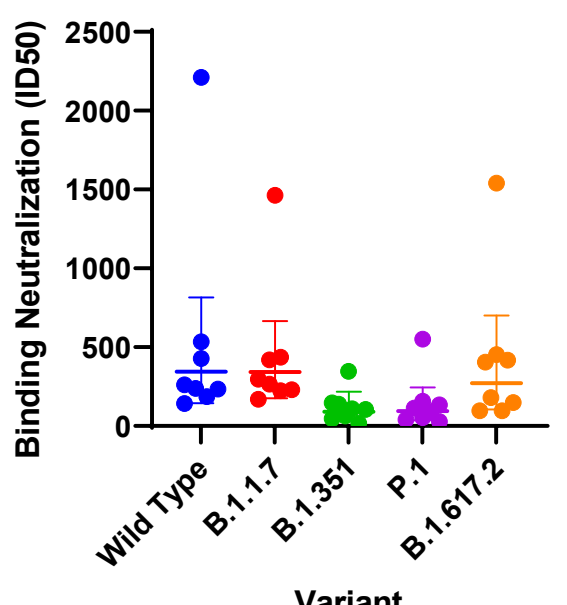

Variant
$2 \mathrm{mg} / \mathrm{kg}$ cohort

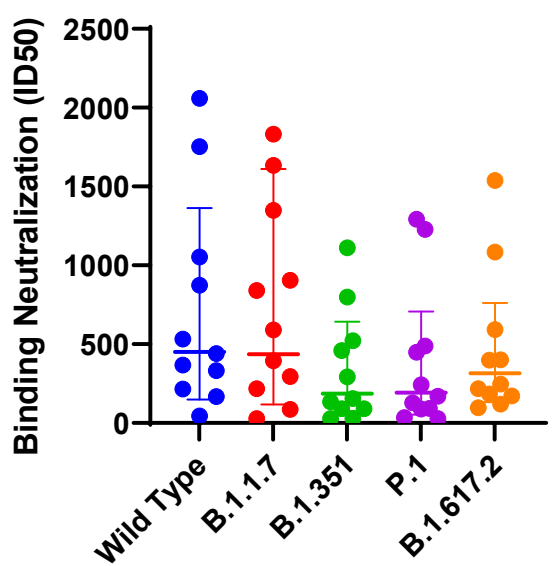

Variant
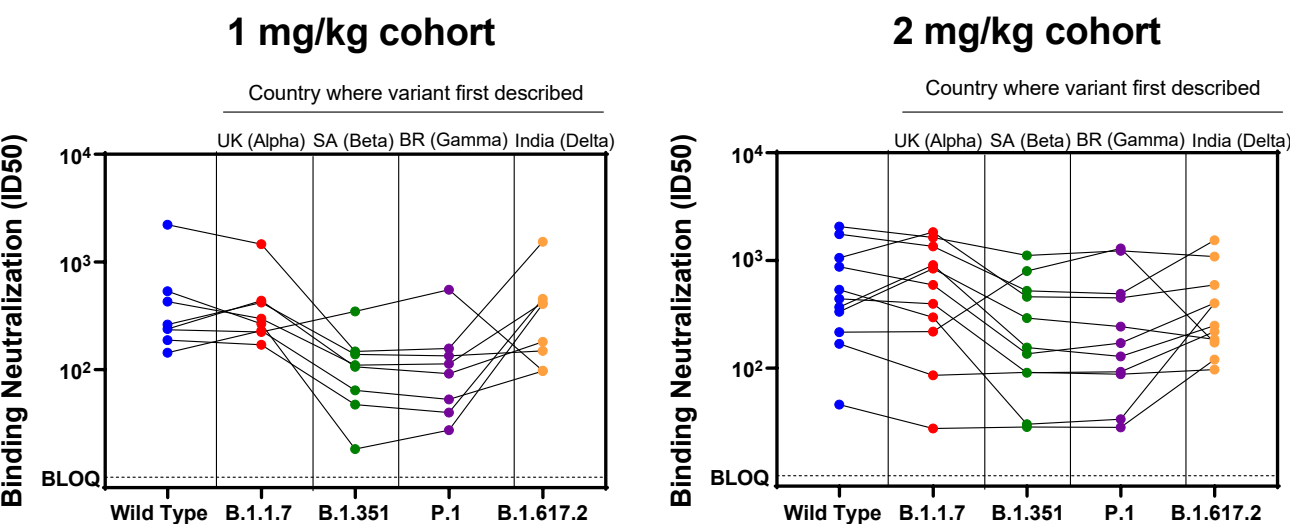
medRxiv preprint doi: https://doi.org/10.1101/2021.09.13.21263406; this version posted September 28,2021 . The copyright holder for this
preprint, (which was not certified by peer review) is the author/funder, who has granted medRxiv a license to display the preprint in perpetuity

Table 1

It is made available under a CC-BY-NC-ND 4.0 International license .

\begin{tabular}{|c|c|c|c|c|c|c|}
\hline $\begin{array}{c}\text { Dose } \\
(\mathrm{mg} / \mathrm{kg})\end{array}$ & $\begin{array}{c}\text { \# of } \\
\text { Patients } \\
\text { Enrolled }\end{array}$ & $\begin{array}{l}\text { Median } \\
\text { Age } \\
\text { (Range) }\end{array}$ & $\begin{array}{c}\text { Onset of } \\
\text { Symptoms } \\
\text { Median (Range) }\end{array}$ & Comorbidities & $\begin{array}{l}\text { Median BMI } \\
\text { (Range) }\end{array}$ & $\begin{array}{l}\text { Median Time } \\
\text { to Discharge } \\
\text { (Range) }\end{array}$ \\
\hline 0.3 & 5 & $48(28-72)$ & $4(1-8)$ & $\begin{array}{l}\text { DM, CAD, HTN, } \\
\text { asthma, cancer }\end{array}$ & $30.3(24.6-33.7)$ & $3(2-4)$ \\
\hline 1.0 & 11 & $67(37-80)$ & $7(3->21)$ & $\begin{array}{l}\text { DM, CAD, HTN, } \\
\text { COPD, } \\
\text { hypothyroidism }\end{array}$ & $32.1(16.5-40.1)$ & $4(2-13)$ \\
\hline 2.0 & 3 & $52(47-85)$ & $5(2-6)$ & $\begin{array}{l}\text { DM, HTN, CAD, } \\
\text { asthma }\end{array}$ & $36.7(23.8-41.8)$ & $3(2-4)$ \\
\hline 3.0 & 5 & $53(26-76)$ & $5(1-9)$ & $\begin{array}{c}\text { DM, HTN, asthma, } \\
\text { cancer }\end{array}$ & 30.7 (26.5-33.9) & $4(2-23)$ \\
\hline 5.0 & 5 & $56(23-68)$ & $5(4-8)$ & $\begin{array}{l}\text { DM, HTN, CKD, } \\
\text { cancer }\end{array}$ & $33.3(23.3-47.5)$ & $4(3-8)$ \\
\hline OVERALL & 29 & $61(23-85)$ & $5(1->21)$ & & $32.1(16.5-47.5)$ & $3(2-23)$ \\
\hline
\end{tabular}


medRxiv preprint doi: https://doi.org/10.1101/2021.09.13.21263406; this version posted September 28,2021 . The copyright holder for this
preprint (which was not certified by peer review) is the author/funder, who has granted medRxiv a license to display the preprint in perpetuity

\begin{tabular}{|c|c|c|c|c|}
\hline Baseline characteristics & $\begin{array}{c}2 \mathrm{mg} / \mathrm{kg}+\mathrm{SOC} \\
(\mathrm{N}=15)\end{array}$ & $\begin{array}{c}1 \mathrm{mg} / \mathrm{kg}+\mathrm{SOC} \\
(\mathrm{N}=14)\end{array}$ & $\begin{array}{l}\text { Placebo + SOC } \\
\quad(\mathrm{N}=11)\end{array}$ & $\begin{array}{c}\text { Total } \\
(\mathrm{N}=40)\end{array}$ \\
\hline Age (yrs.) - Median (range) & $56.0(28,69)$ & $53.0(25,67)$ & $53.0(21,63)$ & $55.0(21,69)$ \\
\hline Gender (Female) - n (\%) & $6(40.0)$ & $3(21.4)$ & $8(72.7)$ & $17(42.5)$ \\
\hline \multicolumn{5}{|l|}{ Race $-n(\%)$} \\
\hline White & $12(80.0)$ & $11(78.6)$ & $8(72.7)$ & $31(77.5)$ \\
\hline African American & $2(13.3)$ & $2(14.3)$ & $2(18.2)$ & $6(15.0)$ \\
\hline Asian & 0 & $1(7.1)$ & $1(9.1)$ & $2(5.0)$ \\
\hline Hispanic or Latino & $6(40.0)$ & $3(21.4)$ & $3(27.3)$ & $12(30.0)$ \\
\hline BMI - Median (range) & $33.10(19.5,61.7)$ & $30.75(20.4,45.6)$ & $38.90(23.7,47.7)$ & $33.15(19.5,61.7)$ \\
\hline \multicolumn{5}{|l|}{ Comorbidities - n (\%) } \\
\hline No comorbidity & $8(53.3)$ & $8(57.1)$ & $6(54.5)$ & $22(55.0)$ \\
\hline At least 1 & $7(46.7)$ & $6(42.9)$ & $5(45.5)$ & $18(45.0)$ \\
\hline \multicolumn{5}{|c|}{ Covid-19 symptoms (most common) - $n(\%)$} \\
\hline Cough & $10(66.7)$ & $9(64.3)$ & $8(72.7)$ & $27(67.5)$ \\
\hline Dyspnea & $9(60.0)$ & $8(57.1)$ & $9(81.8)$ & $26(65.0)$ \\
\hline Fatigue & $5(33.3)$ & $6(42.9)$ & $3(27.3)$ & $14(35.0)$ \\
\hline Loss of smell & $6(40.0)$ & $3(21.4)$ & $4(36.4)$ & $13(32.5)$ \\
\hline Fever & $3(20.0)$ & $6(42.9)$ & $4(36.4)$ & $13(32.5)$ \\
\hline $\begin{array}{l}\text { Onset to Randomization (days) - } \\
\text { Median (range) }\end{array}$ & $7.0(1,13)$ & $3.5(1,24)$ & $8.0(1,12)$ & $7.0(1,24)$ \\
\hline $\begin{array}{l}\text { Hospitalization to Randomization } \\
\text { (hours) - Median (range) }\end{array}$ & $41.1(2,102)$ & $39.5(3,107)$ & $26.0(4,103)$ & $36.4(2,107)$ \\
\hline \multicolumn{5}{|l|}{ 8-point Ordinal Scale - $n$ (\%) } \\
\hline 4 - Hospitalized no $\mathrm{O}_{2}$ & $1(6.7)$ & $3(21.4)$ & $1(9.1)$ & $5(12.5)$ \\
\hline 5 - Hospitalized requiring $\mathrm{O}_{2}$ & $5(33.3)$ & $10(71.4)$ & $7(63.6)$ & $22(55.0)$ \\
\hline $\begin{array}{l}6 \text { - Hospitalized High } \\
\text { flow/non-invasive }\end{array}$ & $9(60.0)$ & $1(7.1)$ & $3(27.3)$ & $13(32.5)$ \\
\hline
\end{tabular}


medRxiv preprint doi: https://doi.org/10.1101/2021.09.13.21263406; this version posted September 28, 2021. The copyright holder for this preprint (which was not certified by peer review) is the author/funder, who has granted medRxiv a license to display the preprint in perpetuity.

\begin{tabular}{|l|c|c|c|}
\hline & $\begin{array}{c}2 \mathrm{mg} / \mathrm{kg}+\mathrm{SOC} \\
(\mathrm{N}=15)\end{array}$ & $\begin{array}{c}1 \mathrm{mg} / \mathrm{kg}+\mathrm{SOC} \\
(\mathrm{N}=14)\end{array}$ & $\begin{array}{c}\text { Placebo }+ \text { SOC } \\
(\mathrm{N}=11)\end{array}$ \\
\hline Free from Respiratory Failure or Death - (\%) & 93.3 & 85.7 & 81.1 \\
\hline Median Days to Discharge $(95 \% \mathrm{Cl})$ & $6.0(4-12)$ & $4.0(2-5)$ & $7.0(2-12)$ \\
\hline Median Days to Improvement $(95 \% \mathrm{Cl})$ & $7.0(4-9)$ & $5.5(3-14)$ & $11.0(2-14)$ \\
\hline Median Days Sustained Improve (95\% Cl) & $8.0(4-12)$ & $6.0(3-14)$ & $11.0(2-21)$ \\
\hline
\end{tabular}

